\title{
Menuju Good Governance: Inovasi Pelayanan Publik Berbasis Digital di Kantor Imigrasi Kelas II Non-TPI Kediri Jawa Timur
}

\author{
Abdul Basir Donny Polanunu ${ }^{1}$; Najamuddin Khairur Rijal ${ }^{2 *}$ \\ ${ }^{1}$ Program Studi Hubungan Internasional Universitas Muhammadiyah Malang, \\ abbasdonny@gmail.com \\ ${ }^{2}$ Program Studi Hubungan Internasional Universitas Muhammadiyah Malang, \\ najamuddin@umm.ac.id (* Corresponding Author)
}

\begin{abstract}
Abstrak
Penelitian ini mengkaji tentang bagaimana inovasi pelayanan publik berbasis digital dilakukan oleh Kantor Imigrasi Kediri. Inovasi pelayanan publik berbasis digital ini merupakan salah satu upaya mewujudkan tata kelola pemerintahan yang baik (good governance). Pentingnya good governance tidak terlepas dari problematika pelayanan publik yang selama ini menjadi persoalan tersediri, khususnya berkaitan dengan efisiensi layanan. Hal itulah yang mendasari Kantor Imigrasi Kediri mengembangkan berbagai inovasi berbasis digital dalam upaya memberikan pelayanan prima. Melalui pengumpulan data dari wawancara dan observasi serta didukung dengan sumber kepustakaan, hasil penelitian menunjukkan bahwa berbagai inovasi pelayanan publik dilakukan Kantor Imigrasi Kediri. Inovasi tersebut seperti aplikasi antrian paspor online, Whastapp Gateway, layanan tanpa turun, eazy passport, serta halte ramah HAM. Hal tersebut sebagai realisasi slogan I'm Redi Dinanti menuju terwujudnya good governance.
\end{abstract}

Kata kunci : Good governance, Kediri, Keimigrasian, Pelayanan Publik.

\begin{abstract}
This study examines how digital-based public service innovation is carried out by the Kediri Immigration Office. This digital-based public service innovation is an effort to realize good governance. The importance of good governance is inseparable from the problems of public services, which have been their own problems, especially those related to service efficiency. That is what underlies the Kediri Immigration Office to develop various digital-based innovations in an effort to provide excellent service. Through data collection from interviews and observations and supported by literature sources, the results of the study indicate that various public service innovations have been carried out by the Kediri Immigration Office. These innovations include an online passport queue application, Whastapp Gateway, drive-thru, eazy passports, and human rights-friendly stops. This is a realization of the slogan I'm Redi Dinanti towards the realization of good governance.
\end{abstract}

Keywords : Good governance, immigration, Kediri, public service 


\section{Pendahuluan}

Penelitian ini mengkaji mengenai inovasi pelayanan publik berbasis digital untuk mewujudkan tata kelola pemerintahan yang baik (good governance) yang dilakukan oleh Kantor Imigrasi Kelas II Non Tempat Pemeriksaan Imigrasi (Non TPI) Kediri, Jawa Timur (selanjutnya ditulis Kantor Imigrasi Kediri). Kajian tentang pelayanan publik, khususnya berbasis digital, ini menjadi penting di era kontemporer. Seiring dengan perkembangan globalisasi melalui perubahan revolusioner di bidang teknologi informasi dan komunikasi, berbagai penyesuaian dan inovasi dalam aktivitas pelayanan publik perlu dilakukan dalam rangka memberikan pelayanan prima kepada masyarakat.

Menurut Holle, pada masa kontemporer ini masalah pelayanan publik masih menjadi problematika yang harus diperbaiki oleh negara-negara di dunia (Holle, 2011). Hal itu disebabkan masih banyak terjadi praktik maladministrasi seperti korupsi, kolusi, nepotisme, dan lain-lain dalam aktivitas pelayanan publik. Karena itu, gagasan good governance banyak digaungkan sebagai suatu alternatif sekaligus tujuan utama sistem pemerintahan kontemporer. Ide pokok dari gagasan good governance ialah menuju pengelolaan pemerintahan yang transparan dan efektif dalam melayani segala bentuk kebutuhan masyarakat sehingga pemerintah dapat mendapatkan legitimasi atas otoritasnya (Lockwood, 2010).

Secara mendasar, good governance dapat dimulai dari pembenahan kerangka berpikir aparatur pemerintahan untuk dapat menjaga integritasnya sebagai akselerator kepentingan publik (Lockwood, 2010). Kemudian pemerintah juga dituntut untuk dapat mencetuskan inovasi layanan yang menyesuaikan diri dengan kebutuhan masyarakat agar semua urusan dapat dikoordinasikan dengan ringkas tanpa harus melalui prosesur administrasi birokratis yang rumit dan berbelit. Dengan begitu, tujuan untuk menuju sistem pemerintahan yang lebih ideal dapat berjalan dengan baik.

Selama ini, paradigma lama pemerintahan cenderung berpusat pada kekuasaan. Adanya paradigma baru, seiring dengan perkembangan demokratisasi di Indonesia, mendorong kecenderungan pemerintah berorientasi pada melayani dan memberdayakan masyarakat sesuai dengan konsep good governance. Menurut 
Manan dan Harijanti, tuntutan penyelenggaraan pemerintahan yang baik terutama ditujukan pada pembaharuan administrasi negara dan penegakan hukum (Manan \& Harijanti, 2016). Sebab, jika sistem administrasi negaranya rusak maka sistem hukum dan yang lainnya akan ikut rusak dan cita-cita akan terwujudnya lingkungan pemerintahan yang baik akan sulit dicapai.

Dalam konteks itu, sejak tahun 2008, Indonesia telah memulai sebuah momentum baru dalam era keterbukaan publik seiring dengan disahkannya Undang-Undang Nomor 14 Tahun 2008 Tentang Keterbukaan Informasi Publik (KIP). Keterbukaan informasi publik sangat penting karena masyarakat dapat mengontrol setiap langkah dan kebijakan yang diambil oleh lembaga publik. Keterbukaan informasi publik merupakan bagian penting dari penyelenggaraan pelayanan publik juga merupakan hak yang sangat penting dan strategis bagi warga negara untuk menuju akses terhadap hak-hak lainnya. Buruknya kinerja pelayanan publik selama ini antara lain dikarenakan belum dilaksanakannya transparansi dan partisipasi dalam penyelenggaraan pelayanan publik (Cahyadi, 2017).

Berkaitan dengan hal tersebut, pemerintah Indonesia mengadopsi ide good governance ke dalam agenda reformasi birokrasi. Hal itu tertuang dalam Peraturan Menteri (Permen) Pendayaguanaan Apartur Negara dan Reformasi Birokrasi Indonesia Nomor 11 Tahun 2015 tentang Road Map Reformasi Birokrasi Indonesia 2015-2019 (Prasojo \& Kurniawan, 2008). Singkatnya, pada pemetaan tersebut pemerintah Indonesia memiliki tujuan bahwa reformasi birokrasi dapat menciptakan kondisi bebas korupsi, kolusi, dan nepotisme (KKN), akuntabel, dan menciptakan layanan publik yang berkualitas.

Amanat sebagaimana tertuang dalam Permen tersebut selanjutnya harus diterapkan oleh seluruh instansi pemerintahan di Indonesia, salah satunya Kantor Imigrasi Kediri. Beberapa inovasi layanan Kantor Imigrasi Kediri diarahkan pada upaya untuk mewujudkan reformasi birokrasi melalui digitalisasi pelayanan publik. Penelitian terkait pelayanan publik berbasis teknologi informasi menuju terwujudnya good governance, khususnya di kantor imigrasi, sejatinya telah dilakukan oleh beberapa peneliti sebelumnya. 
Purwastuti, Cikusin, dan Hayat meneliti mengenai pelayanan publik berbasis good governance di Kantor Imigrasi Kelas I Malang (Purwastuti, Cikusin, \& Hayat, 2020). Hal yang sama dilakukan Samsara dengan meneliti inovasi pelayanan paspor di Kantor Imigrasi Klas 1 Khusus Surabaya (Samsara, 2013), maupun Handrisal, Nazaki, dan Hafiz dengan studi pada Kantor Imigrasi Kelas 1 Tanjungpinang (Handrisal, Nazaki, \& Hafiz, 2021). Demikian pula Wilonotomo dan Aji serta Nurmalasyiah mengkaji penggunaan teknologi informasi dalam pembuatan paspor sebagai upaya percepatan pelayanan publik (Nurmalasyiah, 2016; Wilonotomo \& Aji, 2018).

Semua penelitian terdahulu yang disebut di atas fokus pada pelayanan pembuatan paspor yang inovatif dengan memanfaatkan teknologi informasi berupa aplikasi. Pada hakikatnya fokus penelitian ini sama dengan penelitian terdahulu ang disebut di atas. Namun demikian, penelitian ini tidak hanya mengkaji inovasi digitalisasi pelayanan publik di kantor imigrasi. Tetapi juga melihat bahwa pelayanan publik yang inovatif tersebut pelu didukung dengan penciptaan suasana pelayanan yang ramah, inklusif, dan menyenangkan, di mana hal tersebut dilakukan di Kantor Imigrasi Kediri.

Lebih lanjut, diskursus tentang good governance sendiri telah menjadi tema penting dalam berbagai pemahasan terkait pelayanan publik dalam beberapa tahun terakhir. World Bank menjadi salah satu aktor utama penggagas konsep good governance. Konsep ini didasari oleh asumsi bahwa tata kelola pemerintahan yang baik dapat menjadi pondasi pembangunan berkelanjutan secara signifikan. Good governance diartikan sebagai pengelolaan pemerintahan yang terbuka dan dijalankan sesuai etos kerja dan integritas apartur negara (World Bank, 1994).

Menurut World Bank, terdapat tiga karakteristik berjalannya tata kelola pemerintahan yang baik (World Bank, 1994). Pertama, Participation, berarti seluruh lapisan masyarakat ataupun objek kebijakan juga harus dilibatkan dalam kebijakan yang akan dikeluarkan. Hal ini dilakukan agar segala hal yang dilakukan oleh pemerintah dapat merepresentasikan aspirasi dari masyarakat. Kedua, Rule of Law, berarti harus adanya jaminan bahwa pemerintah dapat bersikap objektif terhadap pemenuhan kepentingan dan kebutuhan masyarakat. Seluruh objek 
kebijakan harus dianggap sama rata tanpa mengistimewakan golongan-golongan tertentu. Aspek ini pula yang menekan bahwa praktik korupsi, kolusi, dan nepotisme harus dihentikan guna menciptakan sistem pemerintahan yang bersih. Ketiga, Accountability, berarti pemerintah diharuskan mampu bertanggung jawab atas perannya sebagai pelayan masyarakat.

Lebih lanjut, menurut Camdessus, good governance ialah sebuah tata kelola pemerintahan yang mampu menerapkan karakteristik efisien dan transparan di setiap urusan administrasinya (Camdessus, 1997). Karena dengan begitu, pemerintah selaku regulator perekonomian negara akan menjadi garda terdepan sebagai pihak yang berperan untuk meningkatkan perekonomian negara. Dengan kedua hal itu (transparansi dan efisiensi), diharapkan urusan administrasi pelaku ekonomi akan semakin mudah terpenuhi dan terkontrol serta hambatan pertumbuhan ekonomi seperti praktik korupsi atau hambatan lainnya semakin bisa diminimalisir (Grindle, 1997). Berangkat dari itulah pertumbuhan perekonomian dapat terealisasi secara bertahap.

Sementara itu, United Nations Development Programme (UNDP) menafsirkan good governance sebagai proses yang mengkoordinasikan dimensi ekonomi, politik, dan sosial untuk mengelola urusan pemerintahan negara (Elahi, 2009). Proses tersebut dimaksudkan agar urusan dari ketiga aspek tersebut dapat menyentuh kepentingan masyarakat dari segala kalangan. UNDP menjabarkan beberapa karakteristik good governance yang lebih kompleks, diantaranya; transparansi, partisipasi, jaminan hukum, responsivitas, berorientasi pada konsensus, akuntabilitas, kesetaraan, visi yang strategis, efektif, dan efisien (Briguglio, Cordina, Farrugia, \& Vella, 2008).

Berdasarkan beberapa pemaparan di atas, maka dapat dipahami bahwa good governance merupakan seperangkat tata kelola pemerintahan yang bersifat efisien dan terbuka serta menjamin adanya kepastian hukum untuk memenuhi kebutuhan mmasyarakatnya. Secara eksplisit, tata kelola pemerintahan yang baik akan bertujuan untuk menuju pada kondisi dimana aspek politik, sosial, dan ekonomi dapat mengalami kemajuan dan perkembangan melalui dasar visi yang strategis. Dalam konteks tulisan ini, gagasan good governance berusaha 
diimplementasikan melalui pelayanan yang dilakukan oleh Kantor Imigrasi Kediri melalui berbagai layanan digital. Berdasarkan paparan tersebut, maka tujuan penelitian ini adalah mengetahui dan menggambarkan inovasi pelayanan publik berbasis digital, yang dilakukan oleh Kantor Imigrasi Kediri sebagai upaya mewujudkan good governance di bidang pelayanan keimigrasian.

\section{Metode}

Ditinjau dari aspek metodologis, penelitian ini menggunakan pendekatan kualitatif. Ditinjau dari tujuannya, penelitian ini merupakan jenis penelitian deskriptif. Menurut Raco, dalam penyusunan penulisan penelitian deskriptif cenderung menyajikan paparan menggunakan uraian narasi penjelas dan dieksekusi menggunakan pendekatan deskriptif agar pembaca dapat memahami arah penjelasan secara terperinci (Raco, 2010).

Adapun lokasi penelitian ini adalah di Kantor Imigrasi Kelas II Non-TPI Kediri, Jawa Timur. Jenis data dalam penelitian ini adalah data primer dan data sekunder. Data primer diperoleh melalui wawancara kepada pegawai Kantor Imigrasi Kediri dan hasil observasi peneliti. Data sekunder diperoleh melalui penelusuran sumber-sumber kepustakaan. Sementara itu, teknik analisis data dalam penelitian ini melibatkan empat tahapan, yaitu pengumpulan data, kondensasi atau reduksi data, penyajian data, serta penarikan kesimpulan (Miles, Huberman, \& Saldana, 2014).

\section{Hasil dan Pembahasan}

\section{Good Governance dan Reformasi Birokrasi}

Problematika pelayanan publik masih menjadi masalah tersendiri dalam sistem pemerintahan. Alasan seperti rumitnya prosedur layanan hingga praktik maladministrasi masih menjadi akar permasalahan mengapa aspek pelayanan publik dalam tata kelola pemerintahan masih menjadi pekerjaan rumah. Asumsi tersebut diperkuat oleh penelitian Cortes-Cediel dkk., bahwa seiring dengan pesatnya perkembangan zaman, banyak muncul permasalahan dalam tatanan masyarakat, dan masalah pelayanan publik merupakan salah satunya (Cortés- 
Cediel, Cantador, \& Gil, 2017). Padahal ketersediaan dan kualitas pelayanan publik bagi masyarakat merupakan salah satu unsur yang krusial dalam menunjang kehidupan masyarakat perkotaan sebagai pusat aktivitas ekonomi, sosial, politik, dan kebudayaan.

Dalam menanggulangi permasalahan-permasalahan tersebut, PPB bekerja sama dengan berbagai lembaga mitra melakukan survei. Hasilnya, ada empat prioritas utama yang perlu mendapatkan perhatian dari masyarakat dunia, yaitu pendidikan yang bermutu, kesehatan yang lebih baik, lapangan kerja yang lebih banyak, dan yang terakhir adalah tata pemerintahan yang jujur dan tanggap (CortésCediel et al., 2017). Untuk itu, negara-negara di dunia merumuskan strategi pengimplementasian good governance yang dimuat dalam Sustainable Development Goals (SDG's), tujuan ke-16, yakni peace, justice, and strong institutions. Tujuan SDG's ke-16 ini secara garis besar untuk menghilangkan hambatan dalam upaya menciptakan perencanaan pengelolaan pemerintahan dengan menggunakan pendekatan yang berkeadilan dan memenangkan kepentingan masyarakat (United Nations, 2017).

Lebih lanjut, adopsi ide good governance oleh pemerintah Indonesia telah diterapkan dengan adanya Grand Design Reformasi Birokrasi Indonesia 2010-2025 (Haning, 2018). Dalam dokumen tersebut, pemerintah Indonesia memproyeksikan kapabilitas pengelolaan pemerintahan dapat meningkat secara konsisten dan juga mampu menjadi tata kelola pemerintahan berkelas dunia. Dalam rangka mewujudkan itu, penerapan good governance yang dilakukan di Indonesia harus senantiasa memenuhi beberapa prinsip (Kementerian Pendayagunaan Aparatur Negara dan Reformasi Birokrasi, 2010).

Pertama, Outcomes Oriented, berarti segala bentuk inisiasi harus memperhitungkan keselarasan dengan tujuan yang ditentukan. Hal itu juga termasuk akumulasi keberhasilan pencapaian tindakan yang dilakukan. Kedua, Terukur, berarti segala bentuk inisiasi menyesuaikan diri dengan hasil yang ingin dicapai. Termasuk bagaimana mekanisme, sasaran, tingkat keberhasilan kebijakan harus terukur secara sistematis. Ketiga, Efektif dan Efisien, berarti kebijakan yang dilakukan harus memuat nilai utama dari reformasi birokrasi yakni memangkas 
segala kerumitan yang mungkin terjadi, sehingga dapat memudahkan kepentingan masyarakat. Kemudian, keempat, Realistik, berarti segala bentuk inisisasi harus disusun secara rasional dan menyesuaikan ide dengan kondisi yang ada agar dapat dicapai secara optimal.

Lebih lanjut, kelima, Konsisten, berarti inisiasi atau kebijakan yang sudah dicetuskan dan diputuskan dengan matang wajib dijalankan sesuai standar pelaksanaan teknis secara konsisten agar mencapai hasil yang sudah ditentukan. Keenam, Sinergi, berarti setiap kegiatan yang ada harus saling membawa dampak positif dari segala variabel yang ada. Hal ini diharapkan agar setiap tindakan yang dilakukan saling berkesinambungan antara satu sama lain dan juga membawa dampak positif bagi proses pencapaian tujuan reformasi birokrasi. Ketujuh, Inovatif, berarti rancangan gagasan ini memberikan ruang yang bebas bagi setiap instansi pemerintahan untuk memberikan inovasi terbaiknya dalam melayani masyarakat. Tentunya inovasi yang diberikan harus memperhatikan prinsip lainnya agar dapat terlaksana secara beriringan menuju tujuan yang diharapkan. Kedelapan, Kepatuhan, berarti reformasi birokrasi harus dilaksanakan sesuai dengan aturan dan perundang-undangan yang berlaku. Serta kesembilan, Monitoring, berarti reformasi birokrasi harus dilakukan dengan adanya pemantauan di setiap tahapan terlaksananya kebijakan agar setiap langkah yang ada dapat terukur perkembangannya.

Prinsip yang sudah dipaparkan di atas menjadi pedoman utama setiap instansi pemerintahan dalam berproses menuju reformasi birokrasi. Namun, di samping itu terdapat pula instruksi pendukung yang diuraikan guna mengkonsolidasikan langkah bersama menuju reformasi birokrasi. UndangUndang No 23 Tahun 2014 Pasal 11 tentang Pemerintahan Daerah mengamanatkan kepada instansi pemerintahan beserta unit pelaksana teknis yang ada untuk menciptakan pelayanan publik yang baik (Angraini, 2015). Berbagai instansi pemerintahan dan juga unit pelaksana teknis yang ada dianjurkan dapat memanfaatkan perkembangan teknologi dalam implementasi upaya menuju reformasi birokrasi. Salah satunya adalah dengan penerapan e-government yang akan berdampak pada kinerja pemerintah dalam melaksanakan pelayanan publik 
yang baik dan transparan. Salah satunya kemudian berusaha dilakukan oleh Kantor Imigrasi Kediri.

\section{Kantor Imigrasi Kediri dan Fungsi Keimigrasian}

Kantor Imigrasi Kediri berdiri dan diresmikan oleh Menteri Hukum dan HAM Amir Syamsudin pada 27 April 2012 sebagai kantor imigrasi kelas III. Dalam perkembangannya, pada tahun 2019, Kantor Imigrasi Kediri telah naik kelas menjadi Kelas II sekaligus menempati gedung baru di Jalan Jawa No.135, Bedrek Selatan, Desa Grogol, Kec. Grogol, Kab. Kediri. Adapun wilayah kerjanya meliputi Kota Kediri, Kabupaten Kediri, Kabupaten Jombang dan Kabupaten Nganjuk (Kantor Imigrasi Kelas II Non-TPI Kediri, 2020e).

Sesuai dengan amanat dalam Undang-Undang Nomor 6 Tahun 2011 tentang Keimigrasian, Kantor Imigrasi Kediri melaksanakan fungsi-fungsi keimigrasian sebagai bagian dari tugas penyelenggaraan negara di bidang pelayanan dan perlindungan masyarakat, penegakan hukum keimigrasian serta fasilitator penunjang pembangunan ekonomi nasional. Adapun fungsi keimigrasian yang dijalankan oleh Kantor Imigrasi Kediri dalam bidang lalu lintas dan status keimigrasian antara lain adalah penerbitan Paspor RI, pemberian perpanjangan Ijin Tinggal Kunjungan, pemberian Ijin Tinggal Terbatas, pemrosesan alih status Ijin Tinggal Kunjungan menjadi Ijin Tinggal Tetap, serta pemrosesan berbagai hal terkait keimigrasian di bidang kewarganegaraan sebagaimana diatur dalam Undang-undang Nomor 12 Tahun 2006 tentang Kewarganegaraan RI (Nurwilianto, 2020).

Dalam bidang penerbitan Paspor RI, Kantor Imigrasi Kediri yang bertanggungjawab secara teknis operasional kepada Direktorat Jenderal Imigrasi telah menerapkan sistem penerbitan paspor yang berbasis pada jaringan yang telah terintegrasi. Sistem penerbitan paspor ini berbasis pada data biometrik yang dikelola dalam satu jaringan terpadu yang terpusat di Direktorat Jenderal Imigrasi Kemenkumham. Menurut Kasubsi Informasi dan Komunikasi Keimigrasian Kantor Imigrasi Kediri Afif Nurwilianto, hal ini paling tidak telah membuat terobosan penting antara lain bahwa setiap warga negara Indonesia dapat mengajukan 
permohonan Paspor RI di seluruh wilayah Indonesia dan di seluruh perwakilan RI di luar negeri serta mencegah adanya penggunaan paspor ganda oleh satu orang warga negara Indonesia (Nurwilianto, 2020).

Berdasarkan data Kantor Imigrasi Kediri, sejak pertama kali didirikan pada tahun 2012, telah melakukan penerbitan paspor sejumlah 41.589 buah Paspor RI 24 halaman, dan 34.244 buah Paspor RI 48 halaman. Selain itu, Kantor Imigrasi Kediri juga telah memberikan perpanjangan Ijin Tinggal Kunjungan sebanyak 399 permohonan, juga 476 permohonan untuk penerbitan Ijin Tinggal Terbatas (Nurwilianto, 2020). Sementara itu, dalam menjalankan fungsi keimigrasian terhadap Warga Negara Asing (WNA), asas domisili masih dijadikan sebagai acuan sebagaimana yang telah diamanatkan dalam Undang-undang Nomor 6 Tahun 2011 tentang Keimigrasian. Pada prinsipnya pelayanan yang diberikan oleh Kantor Imigrasi Kediri terhadap WNA adalah mereka yang bertempat tinggal dan berdomisili di wilayah kerja Kantor Imigrasi Kediri.

Lebih lanjut, Direktorat Jenderal Imigrasi telah berhasil membangun suatu Sistem Informasi Manajemen Keimigrasian sebagai sarana pelaksanaan fungsi keimigrasian di dalam atau di luar wilayah Indonesia. Sistem ini telah dapat menghubungkan berbagai aplikasi fungsi-fungsi keimigrasian di seluruh Kantor Imigrasi, Tempat Pemeriksaan Imigrasi, Rumah Detensi Imigrasi dan seluruh perwakilan RI di luar negeri. Data yang ada dalam Sistem Informasi Manajemen Keimigrasian ini dapat ditemukan seluruh rekam jejak setiap orang yang melintas masuk atau keluar wilayah Indonesia melalui Tempat Pemeriksaan Imigrasi dan data pemohon Paspor RI maupun warga negara asing yang memiliki Ijin Tinggal di Indonesia. Hal ini merupakan pengejawantahan upaya tata kelola pemerintahan yang baik berbasis digital, khususnya dalam hal pelayanan keimigrasian.

\section{Kantor Imigrasi Kediri dan Fungsi Keimigrasian}

Kantor Imigrasi Kediri merupakan unit pelaksana teknis pemerintahan pusat di bawah Kementerian Hukum dan Hak Asasi Manusia (Kemenkumham). Dalam menjalankan tugas pokok dan fungsinya, Kantor Imigrasi Kediri berusaha menjalankan agenda reformasi birokrasi dan mendorong terwujudnya tata kelola 
pemerintahan yang baik. Hal itu terbukti dengan prestasi yang diperolehnya pada 19 Desember 2020. Kantor Imigrasi Kediri dinobatkan sebagai salah satu instansi yang mendapatkan predikat Wilayah Bebas Korupsi (WBK) dan Wilayah Birokrasi Bersih dan Melayani (WBBM) dari Kemenkumham RI (Kantor Imigrasi Kelas II Non-TPI Kediri, 2020d). Predikat tersebut diperoleh atas dasar upayanya dalam membenahi kualitas dan kapabiltas pelayanan publik di bidang keimigrasian.

Berdasarkan hasil wawancara yang telah dilakukan, menurut Kepala Urusan Kepegawaian Kantor Imigrasi Kediri Surya Adi Catur Putra, salah satu kunci perolehan predikat yang diterima oleh Kantor Imigrasi Kediri adalah pengimplementasian pelayanan publik yang inovatif dan menyesuaikan dengan kebutuhan masyarakat (Putra, 2020). Selain itu, Kantor Imigrasi Kediri juga memanfaatkan perkembangan teknologi sebagai bagian dari pelayanan prima pada masyarakat. Beberapa inovasi unggulan pelayanan publik berbasis digital yang telah dicetuskan oleh Kantor Imigrasi Kediri ialah Antrian Paspor Online (APAPO), Whatsapp Gateway, serta Layanan Tanpa Turun (Lantatur) atau Drivethru pengambilan paspor (Putra, 2020).

Pertama, Antrian Paspor Online (APAPO) merupakan sistem pelayanan antrian paspor berbasis digital dan diakses secara dalam jaringan (daring). Lahirnya inovasi ini didasari oleh kondisi di mana pemohon akan menghabiskan banyak waktu saat melakukan proses antrian seleksi berkas pembuatan paspor, karena memang pengecekan berkas paspor membutuhkan waktu yang lama dalam proses seleksi. Kehadiran APAPO diharapkan menjadi solusi atas permasalahan ini, karena prosedur dalam inovasi ini akan lebih mengefesiensikan waktu yang dimiliki pemohon. Pemohon hanya butuh mengakses aplikasi APAPO, kemudian melakukan check-in dengan input keperluan berkas yang dibutuhkan.

Selanjutnya, setelah berkas diverifikasi oleh petugas imigrasi, pemohon akan mendapatkan nomor antrian beserta waktu dan tempat yang telah ditentukan. Setelah mendapatkan nomor antrian, pemohon hanya perlu mendatangi tempat dan waktu sesuai nomor antrian dan mengikuti prosedur singkat guna menyelesaikan urusan administrasi pembuatan paspor. Dengan begitu, kebutuhan waktu dalam pembuatan paspor akan efesien dan lebih singkat. 
Kedua, Whatsapp Gateway. Whatsapp Gateway merupakan layanan berbasis digital yang memberikan informasi umum tentang pelayanan paspor bagi warga negara Indonesia dimulai dari biaya pembuatan, persyaratan yang diperlukan, hingga cek status paspor. Admin operasional dari petugas Kantor Imigrasi Kediri akan membantu memberikan segala informasi yang dibutuhkan oleh pemohon. Salah satu efisiensi dari inovasi Whatsapp Gateway adalah pemohon dapat melakukan cek status paspor yang dibuat sudah sampai tahap selesai atau belum. Jika belum, petugas akan memberitahukan kepada pemohon terkait tahap sebenarnya tentang paspor terkait, kemudian petugas juga akan memberikan estimasi waktu terkait penyelesaian paspor pemohon. Jika sudah selesai, pemohon akan dipersilahkan untuk mengambil paspor di Kantor Imigrasi Kediri. Hal itu sekaligus menonjolkan transparansi instansi pemerintah terkait proses berkas yang sedang dibutuhkan pemohon. Dengan begitu pula, pemohon tidak akan boros waktu untuk datang langsung ke kantor untuk menanyakan status berkas yang dimiliki.

Ketiga, Layanan Tanpa Turun (Lantatur). Lantatur merupakan pelayanan drive-thru pengambilan paspor yang dapat digambarkan seperti pelayanan pada makanan cepat saji. Mekanismenya adalah pemohon akan mendapatkan kode barcode setelah mendapat konfirmasi jika berkas paspor sudah selesai melalui layanan Whatsapp Gateway. Setelah itu, pemohon menyerahkan kode barcode kepada petugas Kantor Imigrasi Kediri untuk diverifikasi. Jika data sesuai, pemohon tinggal mengambil berkas paspor yang dimiliki pada loket drive-thru tanpa harus mengikuti prosedur konvensional.

Keempat, Eazy Passport, merupakan pelayanan paspor secara kolektif yang dilaksanakan di luar kantor imigrasi. Sasaran dari Eazy Passport ini adalah perkantoran/instansi, institus pendidikan, komunitas/organisasi, dan perumahan. Melalui layanan ini, pemohon paspor tidak perlu dating ke kantor imigrasi melainkan petugas imigrasi yang akan dating ke lokasi pemohon paspor dan membantu memberikan pelayanan secara kolektif (Kantor Imigrasi Kelas II NonTPI Kediri, 2020b).

Selain itu, Kantor Imigrasi Kediri juga melakukan inovasi unggulan yang disebut Halte Ramah HAM. Halte Ramah HAM ini merupakan sebuah halte khusus 
untuk memberikan Layanan Ramah HAM. Layanan ini khusus diperuntukkan untuk empat katagori kelompok rentan, yaitu penyandang disabilitas atau orang sakit, lanjut usia (lansia), ibu hamil dan ibu menyusui, serta balita (Kantor Imigrasi Kelas II Non-TPI Kediri, 2020c). Alur kerjanya adalah pemohon kelompok rentan berhenti di Halte Ramah HAM. Kemudian, pemohon memanggil petugas dengan menekan tombol interkom yang terdapat di halte. Selanjutnya, petugas akan segera datang dan mendampingi pemohon menuju Ruang Ramah HAM. Pada ruang inilah pemohon dilayani, berupa pengambilan foto dan biometrik paspor. Setelah proses pemberkasan paspor selesai, pemohon diantarkan kembali oleh petugas menuju Halte Ramah HAM.

Inovasi pelayanan publik di Kantor Imigrasi Kediri, sebagaimana dipaparkan di atas, tidak terlepas dari upaya mewujudkan slogan I'm Redi Dinanti (Imigrasi Kediri, Dedikasi Melayani dengan Sepenuh Hati). Slogan I'm Redi Dinanti ini memiliki makna yang mendasari berbagai pelayanan yang dilakukan oleh Kantor Imigrasi Kediri. Pertama, I'm Redi merupakan kreativitas penyebutan dari Imigrasi Kediri. I'm Redi ini diasosiasikan seperti pelafalan I'm Ready dalam bahasa Inggris, yang berarti "saya siap". Mengapa "saya siap"?. Berdasarkan penjelasan pada brosur arti logo dan slogan Zona Integritas Kantor Imigrasi Kediri, "saya siap" karena perubahan harus berawal dan berasal dari diri sendiri. Perubahan dan kesiapan diri sendiri ini selanjutnya merepresentasikan kesiapan institusi untuk memberikan pelayanan terbaiknya (Kantor Imigrasi Kelas II Non-TPI Kediri, 2020a). Maknanya bahwa setiap petugas di Kantor Imigrasi Kediri siap memberikan pelayanan prima kepada masyarakat.

Kedua, Dinanti merupakan singkatan dari Dedikasi Melayani dengan Sepenuh Hati. Dinanti merupakan bentuk komitmen Kantor Imigrasi Kediri untuk melayani masyarakat dengan penuh ketulusan. Sebagaimana mottonya, "Kami Siap Melayani dengan Tulus." Hal itu sejalan pula dengan visinya Kantor Imigrasi Kediri bahwa "Masyarakat memperoleh kepastian hukum".Lebih lanjut, pengejawantahan dari slogan I'm Redi Dinanti ini menghadirkan maskot Kantor Imigrasi Kediri sebagai instansi dengan Wilayah Birokrasi Bersih dan Melayanai (WBBM). Maskot tersebut diberi nama REDI. REDI merupakan sesosok harimau 
atau macan yang mengenakan kostum biru khas seragam petugas Imigrasi. Macan dipilih sebagai lambang kekuatan dan kewibawaan. Selain itu, dalam legenda yang berkembang di masyarakat Kediri, macan dipercaya sebagai jelmaan dari Prabu Jayabaya. Prabu Jayabaya sendiri adalah raja ketiga Kerajaan Kediri serta menjadi raja paling berpengaruh dalam peradaban masyarakat Jawa. Macan Putih diyakini penjelmaan Prabu Jayabaya dan menjadi simbol kemasyuran Tanah Kediri. Adapun warna biru, memiliki makna kepercayaan, ketulusan, kebijaksanaan, kecerdasan serta dapat diandalkan (Kantor Imigrasi Kelas II Non-TPI Kediri, 2020a).

Sedangkan nama REDI merupakan bagian dari slank I'm Redi Dinanti yang menjadi slogan Kantor Imigrasi Kediri. REDI sendiri merupakan singkatan dari nilai (values) yang dimiliki segenap petugas Kantor Imigrasi Kediri, yaitu, Respectful, Excellent, Dedication dan Integrity (Kantor Imigrasi Kelas II Non-TPI Kediri, 2020a). Respectful bermakna melayani dengan ramah, salam, sapa, senyum, sopan, dan santun. Excellent berarti menghadirkan inovasi dan pelayanan terbaik sepenuh hati tanpa diskriminasi. Dedication menunjukkan bahwa seluruh petugas imigrasi di Kantor Imigrasi Kediri selalu siap sedia, penuh pengabdian, dan memberikan kemampuan terbaiknya untuk melayani. Serta, Integrity berarti mengedepankan pelayanan yang jujur, profesional, konsisten, dan tidak ada pungutan liar di luar biaya yang telah diatur sesuai perundang-undangan. Maskot REDI ini diharapkan menggambarkan setiap insan Kantor Imigrasi Kediri yang selalu memberikan segala kekuatan dan kemampuan untuk memberikan inovasi serta pelayanan prima kepada masyarakat. Mereka harus mengedepankan keramahan serta selalu siap sedia dengan tetap memegang nilai-nilai integritas untuk mewujudkan tata kelola pemerintahan yang baik.

Berdasarkan paparan di atas, maka dapat dikatakan bahwa hasil penelitian ini selaras dengan berbagai penelitian sebelumnya yang mengkaji mengenai inovasi pelayanan publik yang menekankan pentingnya pemanfaatan teknologi informasi (Nurmalasyiah, 2016; Samsara, 2013). Pemanfaatan teknologi ini sejalan dengan tuntutan reformasi birokrasi yang mengedepankan pelayanan berbasis electonic government (Handrisal et al., 2021), menuju terwujudnya tata pemerintahan yang baik (Purwastuti et al., 2020). Apa yang dilakukan oleh Kantor Imigrasi Kediri juga 
sejalan dengan tuntutan pelayanan publik keimigrasian yang berbasis pada HAM (Pasaribu \& Briando, 2019). Hal itu sebagai perwujudan tata nilai (core value) dari Kementerian Hukum dan HAM sebagai “payung” institusi keimigrasian.

\section{Kesimpulan}

Ide utama good governance diadopsi oleh Pemerintah Indonesia dengan wujud reformasi birokrasi. Sasaran utama dalam reformasi birokrasi iniialah menciptakan sistem pemerintahan yang bersih, akuntabel, dan berkualitas. Dalam rangka mewujudkan cita-cita tersebut, maka setiap instansi pemerintahan perlu mengedepankan pelayanan prima serta mengembangkan berbagai inovasi dalam pelayanan publik. Kantor Imigrasi Kediri menjadi salah satu instansi pemerintahan yang tengah berupaya mewujudkan hal tersebut. Hal itu dilakukan melalui berbagai inovasi layanan publik berbasis digital seperti APAPO, Whatsapp Gateway, Lantatur, Eazy Passport, dan Halte Ramah HAM. Pentinganya inovasi lepalayan publik berbasis digital ini sejalan dengan tuntutan perkembangan zaman dan kebutuhan masyarakat di era serba digital.

Penelitian ini selanjutnya memberikan kontribusi akademik terhadap kajian pelayanan publik serta diskursus good governance. Meski demikian, diperlukan penelitian lebih lanjut yang membahas inovasi pelayanan publik berbasis digital dalam usaha perwujudan good governance pada berbagai instansi pemerintahan, khususnya keimigrasian sebagai ujung tombak yang menjadi "pintu" masuk dan keluar dari dan ke wilayah Republik Indonesia.

\section{Ucapan Terima Kasih}

Ucapan terima kasih disampaikan kepada Kantor Imigrasi Kediri yang telah memberikan pelayanan prima sehingga penelitian ini dapat diselesaikan. Terima kasih juga kepada Program Studi Hubungan Internasional Universitas Muhammadiyah Malang yang telah memfasilitasi penelitian ini.

\section{Referensi}

Angraini. (2015). Penerapan E-Governtment di Tingkat Kabupaten (Case Study 
Kabupaten Pelalawan Riau). JSI: Jurnal Sistem Informasi, 7(2), 815825. https://doi.org/https://doi.org/10.36706/jsi.v7i2.2269

Briguglio, L., Cordina, G., Farrugia, N., \& Vella, S. (2008). Economic Vulnerability and Resilience: Concepts and Measurements. Oxford Development $\quad$ Studies, $\quad 37(3), \quad 229-247$. https://doi.org/10.1080/13600810903089893

Cahyadi, A. (2017). Penerapan Good Governance Dalam Pelayanan Publik (Studi Tentang Kualitas Pelayanan Elektronik Kartu Tanda Penduduk Berbasis Good Governance Di Kecamatan Sukolilo Surabaya). JPAP: Jurnal Penelitian Administrasi Publik, 3(2), 750-756. https://doi.org/https://doi.org/10.30996/jpap.v3i2.1255

Camdessus, M. (1997). Good Governance: The IMF's Role. Washington DC: International Monetary from https://www.imf.org/external/pubs/ft/exrp/govern/govern.pdf

Cortés-Cediel, M. E., Cantador, I., \& Gil, O. (2017). Recommender systems for egovernance in smart cities: state of the art and research opportunities. In Proceedings of the International Workshop on Recommender Systems for Citizens (CitRec '17) (pp. 1-6). New York: Association for Computing Machinery. https://doi.org/https://doi.org/10.1145/3127325.3128331

Elahi, K. Q.-I. (2009). UNDP on Good Governance. International Journal of Social Economics, $36(12)$, $1167-1180$. https://doi.org/10.1108/03068290910996981

Grindle, M. S. (1997). Getting Good Government: Capacity Building in the Public Sectors of Developing Countries. (M. S. Grindle, Ed.). Harvard: Harvard Kennedy School.

Handrisal, H., Nazaki, N., \& Hafiz, M. (2021). Inovasi Pelayanan Berbasis Electronic Government Melalui Aplikasi Pendaftaran Antrian Paspor Online (Apapo) Di Kantor Imigrasi Kelas I Tanjungpinang Tahun 2019. KEMUDI : Jurnal Ilmu Pemerintahan, 5(2), 179-198. Retrieved from https://ojs.umrah.ac.id/index.php/kemudi/article/view/3104 
Haning, M. T. (2018). Reformasi Birokrasi di Indonesia: Tinjauan Dari Perspektif Administrasi Publik. JAKPP: Jurnal Analisis Kebijakan Dan Pelayanan Publik, 4(1), 25-37. https://doi.org/https://doi.org/10.31947/jakpp.v4i1.5902

Holle, E. S. (2011). Pelayanan Publik Melalui Electronic Government; Upaya Meminimalisir Praktek Maladministrasi Dalam Meningkatkan Public $\begin{array}{llll}\text { Service. } & \text { SASI, } & \text { 21-30. }\end{array}$ https://doi.org/https://doi.org/10.47268/sasi.v17i3.362.

Kantor Imigrasi Kelas II Non-TPI Kediri. (2020a). Arti Logo \& Slogan Zona Integritas Kantor Imigrasi Kediri. Retrieved January 14, 2021, from https://kediri.imigrasi.go.id/wp-content/uploads/2020/08/Arti-LogoZI-Imigrasi-Kediri.pdf

Kantor Imigrasi Kelas II Non-TPI Kediri. (2020b). Eazy Passport. Retrieved January 14, 2021, from https://kediri.imigrasi.go.id/eazy-passport/

Kantor Imigrasi Kelas II Non-TPI Kediri. (2020c). Inovasi Unggulan. Retrieved January 14, 2021, from https://kediri.imigrasi.go.id/inovasi-unggulan/ Kantor Imigrasi Kelas II Non-TPI Kediri. (2020d). Raih Predikat WBK, Kepala Kantor Sampaikan Terimakasih. Retrieved from https://kediri.imigrasi.go.id/raih-predikat-wbk-kepala-kantorsampaikan-terima-kasih/

Kantor Imigrasi Kelas II Non-TPI Kediri. (2020e). Sejarah Singkat. Retrieved January 31, 2021, from https://kediri.imigrasi.go.id/sejarah/

Kementerian Pendayagunaan Aparatur Negara dan Reformasi Birokrasi. (2010).

Grand Design Reformasi Birokrasi Indonesia 2010-2025. Jakarta: Kementerian Pendayagunaan Apartur Negara dan Reformasi Birokrasi.

Retrieved from http://rbkunwas.menpan.go.id/images/pedoman/reformasibirokrasi_PERPRES-NOMOR-81-TAHUN-2010-TENTANGGRAND-DESIGN-REFORMASI-BIROKRASI-2010-2025-.pdf

Lockwood, M. (2010). Good Governance for Terrestrial Protected Areas: A Framework, Principles and Performance Outcomes. Journal of 
Environmental Management, 91(3), 754-766.

https://doi.org/https://doi.org/10.1016/j.jenvman.2009.10.005

Manan, B., \& Harijanti, S. D. (2016). Artikel Kehormatan: Konstitusi dan Hak Asasi Manusia. Padjadjaran Journal of Law, 3(3), 448-467. https://doi.org/https://doi.org/10.22304/pjih.v3.n3.a1

Miles, M. B., Huberman, A. M., \& Saldana, J. (2014). Qualitative Data Analysis, A Methods Sourcebook (3rd ed.). Sage Publications.

Nurmalasyiah. (2016). Teknologi Informasi Percepatan Pelayanan Publik Pembuatan Paspor pada Kantor Imigrasi. Jurnal Ilmiah Administrasi Publik, 2(4), 195-197. Retrieved from https://jiap.ub.ac.id/index.php/jiap/article/view/619/1274

Nurwilianto, A. (2020). Wawancara Tentang Implementasi Pelayanan Publik Berbasis Digital Kantor Imigrasi Kelas II Non TPI Kediri.

Pasaribu, P. Y., \& Briando, B. (2019). Pelayanan Publik Keimigrasian Berbasis HAM sebagai Perwujudan Tata Nilai "PASTI” Kemenkumham. Jurnal Penelitian HAM, 10(1), 39-56. https://doi.org/: http://dx.doi.org/10.30641/ham.2019.10.39-55

Prasojo, E., \& Kurniawan, T. (2008). Reformasi Birokrasi dan Good Governance: Kasus Best Practices dari Sejumlah Daerah di Indonesia. In 5th International Symposium of Journal Antropologi Indonesia. Banjarmasin. Retrieved from https://reformasibirokrasijabar.files.wordpress.com/2018/10/rb-dangood-governance-eko-p.pdf

Purwastuti, G. A. D., Cikusin, Y., \& Hayat, H. (2020). Pelayanan Publik Keimigrasian Berbasis Good Governance (Studi Pada Pembuatan Paspor Di Kantor Imigrasi Kelas 1 Malang). Jurnal Respon Publik, 14(1), 60-67. from http://riset.unisma.ac.id/index.php/rpp/article/view/6052/4947

Putra, C. A. (2020). Wawancara Tentang Implementasi Pelayanan Publik Berbasis Digital Kantor Imigrasi Kelas II Non TPI Kediri.

Raco, J. (2010). Metode Penelitian Kualitatif: Jenis, Karakteristik dan 
Keunggulannya. Jakarta: Grasindo.

Samsara, L. (2013). Teknologi Informasi Percepatan Pelayanan Publik Pembuatan Paspor pada Kantor Imigrasi. Teknologi Informasi Percepatan Pelayanan Publik Pembuatan Paspor Pada Kantor Imigrasi, 1(1), 615. Retrieved from http://journal.unair.ac.id/download-fullpapersLadiatno Samsara.pdf

United Nations. (2017). E-Government for Sustainable Development. New York: Workspace Unpan.

Wilonotomo, W., \& Aji, K. P. (2018). Pelayanan Pembuatan Paspor dalam Kajiannya Terhadap Teori Manfaat Teknologi Informasi. Jurnal Ilmiah Kebijakan Hukum, 12(2), 163-178. https://doi.org/http://dx.doi.org/10.30641/kebijakan.2018.V12.163178

World Bank. (1994). Governance: The World Bank Experience. Washington DC: World Bank Publications. Retrieved from https://documents.worldbank.org/en/publication/documentsreports/documentdetail/711471468765285964/governance-the-worldbanks-experience

\section{Wawancara}

Nurwilianto, A. (2020). Kantor Imigrasi Kediri, Oktober 2020

Putra, C. A. (2020). Kantor Imigrasi Kediri, Oktober 2020 